\title{
A Study of Sino-Western Intercultural Marriage From A Cross-Cultural Prospective
}

\author{
Yunling Sun and Lina Yuan*
}

\author{
College of Humanities and Sciences of Northeast Normal University \\ *Corresponding author. Email:25065600@qq.com
}

\begin{abstract}
With the development of globalization and the frequent communication among cultures and economy, intercultural marriage is becoming more and more popular. Intercultural marriage is a typical representative of cross-cultural communication, which greatly reflects the similarities and differences of diverse cultures. This thesis researches some conflicts and barriers between couples in intercultural marriage from a cross-cultural prospective, and its reasons. The research of this thesis is mainly on the following aspects: first, the status analysis of Sino-Western intercultural marriage; second, the macroscopic and microscopic cultural elements that influence intercultural marriage.
\end{abstract}

Keywords: Cross-culture, Intercultural marriage, Barriers and conflicts.

\section{INTRODUCTION}

Intercultural marriage has existed in China for a long time. Nowadays, with the rapid development of the world economy, more and more countries are willing to open themselves to the outside world, rather than close their countries to international communication. At the beginning, people were only together with passionate love. However, cultural conflicts appeared during marriage life. Not all intercultural couples could live a happy life, because there are cultural differences and conflicts. Family violence, high divorce rates and many other problems often occur in intercultural marriages. All of these problems affect the happiness of intercultural marriages. For most people, marriage is a great turning point in their life. Everyone wants to have a happy marriage life. Therefore, learning how to deal with these problems is very important to intercultural marriage life. Therefore, the objective of the thesis tries to gain reasons for conflicts and barriers in intercultural marriage and put some suggestions about how to reduce these conflicts and barriers in intercultural marriages.

There are five parts in this thesis. Part One is the introduction part, including the overview, background and purpose of the study and overall structure of the thesis. Part Two is a literature review which makes a summary on intercultural marriage abroad and in China, and it also explores the factors that influence intercultural marriage. Part Three is the main part that explores the reasons for conflicts and barriers in intercultural marriage. Part Four puts forward some suggestions for eliminating these conflicts and barriers. The last part gives a conclusion for the whole thesis.

\section{PREVIOUS STUDIES OF INTERCULTURAL MARRIAGE}

\subsection{Study of Intercultural Marriage Abroad}

Before 1990, most literature focused on the social atmosphere of intercultural themes in contemporary publications. After that, relevant theories emerged about reasons of people's choice of intercultural marriage and related attributes, including the specific information of communication and social adaptation.

In 1997, writer Dugan Romano interviewed a number of intercultural couples and outlined 17 challenges to these intercultural marriages. Among the challenges, there are some common problems for those intercultural couples, they are values, eating and dietary habits, gender roles, attitudes toward time, religion, living place, dealing with stress, ethnocentrism and so on. Romano proposed the conflict of intercultural marriage and four styles of conflict resolution that include submission, compromise, elimination and consensus. His study covers many forms of intercultural marriage therefore the result is not so specific but his styles for dealing with marital conflicts can be worthy of intercultural couple's thinking. 
Additionally, studies conducted in Canada and the United States show that women are more likely than men to marry outside their ethnic group. Likewise, those who are older or have a higher level of education are more likely to marry outside their ethnic group.

The study on intercultural romantic relationship experienced a procedure from immature to mature period. It developed from the primary investigation without much theoretical framework to interviewing participants with relevant research attributes. The study content developed from primary phenomenon description to deeply exploration referring to culture elements.

\subsection{Study of Intercultural Marriage in China}

There are more and more intercultural marriages in China and most of other countries. However, studies on intercultural marriage are not very prosperous in China and the main categories are surveys in some academic thesis, tales in blog, magazines and books, advises on how to lead to successful intercultural relationship.

The study on Sino-Western intercultural marriage is limited. Literature consisting of culture study is relevant to this thesis therefore it is necessary to summarize them here. The Culture Conflict and Tangible Solution: $A$ Study on the Sino-Western Intercultural Marriage (2008), written by Yao Jibin, inspires me a lot. Yao applies cross-cultural theories to analyze and resolve those problems in intercultural relationship. He collects intercultural relationship cases to explore the cultural reasons why intercultural relationships can succeed and comes to the conclusion that the degree of acculturation influences the happiness degree of intercultural marriage. Relationship Development of ChineseWesterner Couples in Shanghai-A Qualitative Study (2007) by Zhang Lili studies intercultural relationship in Shanghai city. She focuses on that whether individual attraction possess cultural universality or not, and she also presents the researchers the process of adaptation in the intercultural relationships through studying the relationship between mutual parents and relatives by marriage. This study is more specific and novel; however, critical conclusion and solutions are not available.

\section{REASONS FOR CONFLICTS AND BARRIERS IN INTERCULTURAL MARRIAGE}

\subsection{Different Value Systems}

Human values are defined as a set of rules that people choose to follow unconsciously and help themselves make the right decisions in life. Values are the core of every culture and they guide human behavior. Therefore, value system is an important factor that influences intercultural marriage. As we all know, intercultural couples come from different cultural systems, and it is obviously that these value systems are different. Each value system has its own criteria for judging what is right or wrong, what is good or bad, and what is beautiful or ugly. It can be said that crosscultural couples in conflict are always inconsistent, because they are operated by two different value systems.

Values are learned at home or in the school, and most of time the process is unconscious and it is reinforced by society. Therefore, we can say that values are usually determined by culture.Though having the same fundamental needs, people from different cultures may not only have different social or psychological needs, but also have completely different ways to perceive their needs. So the intercultural couples behave instinctively according to their ways in their own cultural logic. Sometimes it is obviously that the natural for one culture is not always natural for the other.

Sometimes, most spouses don't have a good understanding of their cultural values, although they can do things naturally. And when something went wrong, they can react automatically when their sense of justice was attacked.

Different value systems are mainly manifested in the following aspects: different cultural patterns, in which individualism versus collectivism, high-context communication versus low-context communication, and equality versus hierarchy will be analyzed specifically; different gender identity and role patterns; different diet ad custom.

\subsection{Personal Attitudes}

Besides the differences of cultural patterns, another factor that undermines the Sino-Western marriages is personal attitudes. In my opinion, three personal attitudes of stereotypes, ethnocentrism and prejudice are influencing the intercultural marriage.

\subsubsection{Stereotypes}

The major barrier of communication for intercultural couples is stereotypes. According to an intercultural communication article on the practical advice website Sideroad.com, human nature can lead people to make assumptions about others; some cultures use stereotypes to emphasize these assumptions. A lot of it is based on personal beliefs and personal fears.

\subsubsection{Ethnocentrism}

Ethnocentrism is also the barrier of communication for intercultural couples. Ethnocentrism is the belief that one's own culture is superior to other cultures. This type of thinking directly influences intercultural 
communication, because one person thinks the other group is inferior. There can be no effective communication based on the status of inequality.

\subsection{Communication Barrier}

Good communication is one of the most important factors in a successful marriage, but sometimes it is difficult to achieve for many couples. It may also be difficult to express the deep insecurities, fears, hopes, or even regrets for those couples in a homogeneous marriage. It is more difficult in the intercultural marriage, not only because of the vocabulary that may not be articulated as the result of language differences, but also because of couple's inner anxiety that the spouses cannot understand each other and judge things in a negative way.

In Sino-Western intercultural marriage, some westerners cannot understand thoroughly what their Chinese spouses say or even misunderstand the behaviors happened in Chinese culture. Chinese female migrants are doing their best to learn their husbands' language to overcome such problems. As for the media reports on the negative effects of the migrant mothers' limited language skills on their children's education, female migrants are making greater efforts to improve their foreign language skills. However, regardless of how much effort they do, the female migrants with lower education and less communication skills still face considerable limitations. They still cannot pronouns words precisely, and they still feel it more difficult to put words in the proper order. What's worse, these female migrants lack language skills required in formal contexts and lack technical vocabularies.

\section{SUGGESTIONS FOR ELIMINATING THE CONFLICTS AND BARRIERS IN INTERCULTURAL MARRIAGE}

Although there are still many conflicts involving foreign marriages, some effective strategies can be found to promote cross-cultural communication.

\subsection{Strong Concern to Different Values}

Everyone knows that value is invisible, but it could have an intangible influence in intercultural marriage. Americans attach great importance to personal values. Respecting to the individual is a key point of intercultural marriages. The realization of individual value is the basis of realizing other values. Therefore, it is easy to find that many people have their own unique views, attitudes and values. In a intercultural marriage, both of spouses need to pay high attention to their spouse's values. If intercultural couples couldn't understand their spouse's values, their marriage lives may not be happy. As we know, many Chinese people hope to get help from families or relatives when they are in trouble. On the contrary, most Americans believe that they must rely on themselves and work hard to succeed. Therefore, intercultural couples need to try their best to understand different values, study different cultural resources, respect to different values, and make corresponding adjustments in their marriage life.

\subsection{Seeking Common Ground}

Cultural differences are the biggest challenge of intercultural marriages. A unique culture is a source for the outmoded concept in a unique field. So we want to achieve an exceptional accomplishment intercultural marriages. A distinct understanding of cultural differences is particularly important. The mistakes in understanding of cultural differences can cause a lot of problems in other areas.

Different country has disadvantages and weaknesses. Taboo as it's an important part has its irreplaceable role. It's something you don't want to get into or talk about. Such as western people don't like elephants, they prefer white to red color, so we should avoid it in intercultural marriage. In addition, the differences between traditional customs and manners may cause misunderstanding in different cultural backgrounds. In intercultural marriage lives, you can never enter the taboo field, but to replace the meaning with changed words. In particular, too much emphasis is placed on religious matters, because religion is a strong belief and faith to local citizens. As we all know, "13" is not very popular in the western world. However, if you go into the restricted zone to destroy their faith, even if it's not your main purpose; there might be a war just because of the conflicts. Since taboos occupy a very important position in culture, the prerequisite of the better understanding about taboos is a general understanding of the prominence and inadequacy of a certain culture. Be thoroughly acquainted with taboos, a clear understanding of what you can do and what you should not ignore are prerequisites for winning local support. Therefore, the best thing you can do is to replace as many unlucky words as possible.

In a word, the intercultural couples should find common ground between them. Keep the problem at hand and focus on the immediate problems. It is an entry point of good communication. You and your spouse have the same common goal of trying to make things work; the two of you may learn from each other on how to save your marriage. Everything will be much better tomorrow.

\subsection{Reducing Communication Barrier}

As we all know, good communication is one of the most important factors in a successful marriage, and communication barrier is certainly an important factor 
that impedes intercultural marriage. In intercultural marriage, it is difficult to have appropriate communication with spouses, not only because of differences in languages and cultures, but also because of the anxiety between couples, spouses can't understand each other. Sometimes it could be difficult to express their innermost feelings of insecurity, fear, hope, and even regrets.

Intercultural couples should have confidence in their feelings to their spouse.Talk openly about their feelings and how they really want to work with you. Don't respond with anger or express it with resentment, but say it from the heart. Talk to your spouse about your feelings and allow him or her to talk to you freely.

\subsection{Making Necessary Discussions after Marriage}

There is an important thing to do after marriage for intercultural couples. They should discuss all aspects of their future life together after marriage. There could be some conflicts after marriage. They need to be resolved by using a "win-win" strategy. The "win-win" strategy refers to the process in which both parties try to adapt to different viewpoints through mutual understanding. For example, when they plan to have a baby, they should talk about the way of raising their child and their cultural style in advance. They should explain their own ideas to each other and try to understand each other's ideas. Discussion is very important in marriage life, especially in intercultural marriage life.

Listening to each other and discussing with each other are very important to have a happy marriage life for intercultural couples. Although the way looks informal, sometimes the dialogue after dinner, chatting during walking, or the plans for the weekend can really play an important role in their marriage, and they could deepen mutual understanding and strengthen their marriage.

\section{CONCLUSION}

The world we are living is experiencing enormous changes in many aspects such as in technology, transportation, economic and political reform, which brings great diversity to western countries, and constant expanding population density father catalyzes the world change. Under this tendency, people in one culture increasingly interact with people from another different culture. Intercultural marriage is more and more popular in recent years. Intercultural marriage is highly correlated with international relations. Harmonious coexistence in international relations plays an important role in promoting the formation of intercultural marriage. On the contrary, the deterioration of international relations will have a negative impact on the quantity and quality of intercultural marriages.
In intercultural marriage, couples should not wait for problems to emerge, and they need to take positive actions to avoid misunderstandings and conflicts, and try their best to promote the happiness and to maintain the success of their marriage. Since intercultural marriage is the embodiment of intercultural communication, the analysis of intercultural marriage will have a positive effect on intercultural communication. In the $21 \mathrm{st}$ century, the world has become so small that we are all independent. What happens in one place of the world to improve our intercultural communication skills.

\section{REFERENCES}

[1] Bhagwati, J. In Defense of Globalization: with A New Afterword [M]. Oxford University Press, USA. 2005.

[2] Chen Guo-Ming \& William J. Starosta. Foundations of Intercultural Communication [M]. Lanham. University Press of America, Inc, 2005.

[3] Donovan, S. Stress and Coping Techniques in Successful Intercultural Marriages[D]. Virginia: Virginia Polytechnic Institute and State University, 2004.

[4] Dugan Romano. Intercultural Marriage, Promises and Pitfalls [M]. Boston: Intercultural Press, 2008.

[5] Edmund, Fred. An Introduction to Intercultural Communication: Identities in Global Community [M]. Thousand Oaks: Sage Publications, 2004.

[6] Hall, Bradford J. Among Cultures: the Challenge of Communication [M]. Thomson. Wadsworth. Second Edition. 2002.

[7] Martin, J. N. \& Nakayama, T. K. Intercultural Communication in Context [M]. New York: McGraw-Hill, 2004: 5.

[8] Martin, J. N. \& Nakayama, T. K. Experiencing Intercultural Communication: An Introduction [M]. New York: McGraw-Hill, 2005:156.

[9] Myron W. Lustig\&Jolene Koester. Intercultural Competence: Interpersonal Communication across Cultures [M]. New Jersey: Pearson Education, Inc, 2006.

[10] Nida, E. A. Language and Culture [M], Shanghai: Shanghai Foreign Language Education Press, 2000.

[11] Samovar Larry. A\&Richard E. Porter. Intercultural Communication: A Reader [M]. Belmont, CA. Wadsworth Publishing Company, 2000.

[12] Samovar Larry. A, Richard E. Porter\&Lisa A. Stefani. Communication between Cultures [M]. Beijing: Foreign Language Teaching and Research Press, 2001. 